\title{
Understanding the Changing Landscape of Contemporary Spirituality: A useful starting point for reviewing Catholic school religious education
}

\begin{abstract}
Pope John Paul II, following in the steps of his predecessors, strongly advocated the critical appraisal of the influence of culture on people's spirituality. This article responds to his directive by seeking to develop an interpretation of how and why contemporary spirituality has changed that will better inform the work of religious educators in Catholic schools. A number of constructs like secularisation, privatisation of religion etc. have been used to describe the significant change in spirituality of many of the young people in Australian Catholic schools over the last 50 years from a more traditional religious spirituality to something that is more secular, eclectic and individualistic. To some extent, this change has been acknowledged; but the religion curricula in Catholic schools still give the impression that all of the students are, or should be, regular church goers - as if Sunday mass attendance was to be the end point of their education in spirituality. An interpretation of change in spirituality in terms of change in cultural meanings has been developed for the purpose of understanding contemporary spiritualities in other than a deficit model. Such an interpretation may be more persuasive in getting Catholic education authorities and religious educators firstly to accept, rather than condemn or ignore, the significant change in contemporary spiritualty; and then secondly, to take steps to address this change positively and constructively in the Catholic school religion curriculum. This article is concerned with the first step - understanding contemporary spirituality; it is intended that the second question will be considered in a follow up article.
\end{abstract}

\section{Keywords}

Changes in spirituality, cultural meanings, secularisation, Catholic schools, religious education. 


\section{Introduction}

In his homily in Quebec City in 1984, Pope John Paul II drew attention to what he called the 'culture industry' and the way in which cultural meanings may have a shaping influence on people's thinking and behavior. And he stressed the educational need to critically interrogate these meanings from a gospel perspective. "...to develop your culture with wisdom and prudence, retaining the freedom to criticise what may be called the 'cultural industry' remaining all the while deeply concerned with truth ... faith will ask culture what values it promotes, what destiny it offers to life, what place it makes for the poor and the disinherited with whom the Son of Man is identified, how it conceives of sharing, forgiveness and love"1.

The discussion here responds to this call, firstly by trying to find a way of understanding how and why there has been such significant change in spirituality over the past 60 years. This is a starting point for helping make religious education more relevant and meaningful for young people today. Much has been written about the strong wave of secularisation that has swept over Western countries; but such material is often too esoteric to be of practical use to educators involved in religious education. What is proposed here is a simpler system of interpreting the changes in terms of changes in cultural meanings that have influenced how people understand and respond to the spiritual and moral dimensions to life. Such an approach lends itself to a critical pedagogy where young people can study the influences of culture on spirituality. The first step in this direction is to interpret the changing landscape of spirituality.

Trying to interpret changes in spirituality in relation to socio-cultural change is also a valuable response to the directive in Vatican II's Gaudium et spes, Pastoral Constitution on the Church in the Modern World. "...the Church has always had the duty of scrutinizing the signs of the times and of interpreting them in the light of the Gospel. Thus, in language intelligible to each generation, she can respond to the perennial questions which men ask about this present life and the life to come, and about the relationship of the one to the other. We must therefore recognize and understand the

1 Pope John Paul II, Homily, University of Laval Stadium Quebec City, Canadian Catholic Review, 1984, October, p. 323-325. 
world in which we live, its explanations, its longings, and its often dramatic characteristics"'.

There are two reasons why an understanding of contemporary, relatively secular spirituality is important for Catholic school religious education. Firstly: If religious education is to be relevant to the needs of pupils, it should accept and address constructively the new situation where only a minority will ever become engaged in Catholic parishes. Such an approach is still a genuine and realistic expression of the Catholic school's mission. But a wider acceptance of this thinking seems to need a more insightful interpretation of how contemporary spiritualities have emerged. Secondly: Understanding how spirituality has changed over time in conjunction with social and cultural change can provide valuable insights for education in spirituality; it can inform relevance in both content and pedagogy by helping with the 'diagnosis' and appraisal of new developments and cultural contexts, which inevitably have both healthy and unhealthy aspects.

\section{Change in cultural meanings: A scheme for interpreting how and why spirituality has changed}

The understanding of spirituality assumed here has been outlined in detail in Crawford and Rossiter ${ }^{3}$. What follows will extend that view of how spirituality has evolved.

A range of constructs can be used for interpreting change in spirituality. All of them have some explanatory power; but none by themselves seems to provide an adequate interpretation because change in spirituality is multidimensional. The change is mediated by a complex tapestry of influences that plays out differently for individuals. Table 1 lists a range of sociological constructs that have been used to interpret social change and which in turn can be applied to spirituality. The table signposts the different constructs without attempting to analyse them in any detail. Only a few references are noted as examples; and a number of them touch on the application of the construct to spirituality.

2 Second Vatican Council. Gaudium et spes. 1965, \#4 Vatican website http://www.vatican. va/archive/hist_councils/ii_vatican_council/documents/vat-ii_cons_19651207_gaudium-et-spes_ en.html (07.02.2013).

3 M. Crawford, G. Rossiter, Reasons for living: Education and young people's search for meaning, identity and spirituality. Melbourne 2006, Australian Council for Educational Research. 
Table 1. Range of sociological constructs that can be used for interpreting change in spirituality

\begin{tabular}{|c|c|c|}
\hline $\begin{array}{c}\text { Sociological } \\
\text { construct }\end{array}$ & Notes on the focus of the constructs & References \\
\hline \multicolumn{3}{|c|}{$\begin{array}{l}\text { Constructs related to } \\
\text { religion \& change }\end{array}$} \\
\hline Religiosity & $\begin{array}{l}\text { Measure of religious behaviour such as } \\
\text { attendance at church/synagogue etc., } \\
\text { frequency of prayer, engagement in a local } \\
\text { community of faith. }\end{array}$ & $\begin{array}{l}\text { Glock \& Stark (1965); } \\
\text { Flynn (1985, 1993); } \\
\text { Smith \& Denton }(2005)^{\mathrm{I}} \text {. }\end{array}$ \\
\hline $\begin{array}{l}\text { Churched } \\
\text { / unchurched }\end{array}$ & $\begin{array}{l}\text { Churched-means familiarity with religious } \\
\text { culture and engaged in a parish. } \\
\text { Unchurched-means a lack of religious } \\
\text { culture and no connection with a parish. }\end{array}$ & $\begin{array}{l}\text { Fuller (2001); } \\
\text { Tinsey }(2002) ; \\
\text { Sullivan }(2003)^{\mathrm{II}} \text {. }\end{array}$ \\
\hline Secularisation & $\begin{array}{l}\text { Decline in the prominence of religion in } \\
\text { personal, social and political life; less } \\
\text { reference to the idea of god in spirituality. }\end{array}$ & $\begin{array}{l}\text { Mascall (1965); } \\
\text { Bonhoeffer (1966); } \\
\text { Fenn (2001); } \\
\text { Norman (2002); } \\
\text { Wright (2004); } \\
\text { Crawford \& Rossiter (1996, } \\
\text { 2006) }\end{array}$ \\
\hline $\begin{array}{l}\text { Privatisation of } \\
\text { religion }\end{array}$ & $\begin{array}{l}\text { Religious beliefs increasingly becoming } \\
\text { a private matter, like opinions; decline in the } \\
\text { social prominence of religion. }\end{array}$ & $\begin{array}{l}\text { Baum (1970); } \\
\text { Crawford \& Rossiter (2006) }{ }^{\mathrm{IV}} \text {. }\end{array}$ \\
\hline $\begin{array}{l}\text { Social reality of } \\
\text { religion }\end{array}$ & $\begin{array}{l}\text { People construct a view of what they think } \\
\text { religion is; religious knowledge is socially } \\
\text { constructed. }\end{array}$ & $\begin{array}{l}\text { Berger and Luckmann } \\
(1966), \text { Berger }(1969,1973)^{\mathrm{v}} \text {. }\end{array}$ \\
\hline World views & $\begin{array}{l}\text { A scheme of meaning through which people } \\
\text { make sense of the world and life. A collective } \\
\text { world view may function like a religion. }\end{array}$ & \begin{tabular}{|l|} 
Jackson $(1997) ;$ \\
Olthius $(1985) ;$ \\
Naugle $(2002)^{\mathrm{VI}}$. \\
\end{tabular} \\
\hline \multicolumn{3}{|c|}{$\begin{array}{l}\text { Constructs related to } \\
\text { social change }\end{array}$} \\
\hline Social reality & $\begin{array}{l}\text { Knowledge is constructed through social } \\
\text { interaction; leads to particular, contextual } \\
\text { perceptions of what constitutes reality. }\end{array}$ & $\begin{array}{l}\text { Berger and Luckmann } \\
\text { (1966), Berger (1973), } \\
\text { Blumer (1969) }\end{array}$ \\
\hline $\begin{array}{l}\text { Cultural post } \\
\text { modernity }\end{array}$ & $\begin{array}{l}\text { The cultural situation characterised by:- } \\
\text { uncertainty about personal knowledge, } \\
\text { which is socially constructed and contextual; } \\
\text { disbelief in meta-narratives; extreme } \\
\text { individualism; scepticism; existentialism. }\end{array}$ & $\begin{array}{l}\text { Bauman (1997); } \\
\text { Bridger (2001); } \\
\text { Crawford \& Rossiter (2006) }\end{array}$ \\
\hline $\begin{array}{l}\text { Individualism/ } \\
\text { individualisation }\end{array}$ & $\begin{array}{l}\text { Emphasis on the individual, often at the } \\
\text { expense of a community dimension; } \\
\text { emphasis on individual freedom. }\end{array}$ & $\begin{array}{l}\text { Halman and de Moor (1993); } \\
\text { Crawford \& Rossiter (2006). } \\
\text { Schweitzer (2004, 2007); } \\
\text { Boeve (2007) }\end{array}$ \\
\hline Pluralism & $\begin{array}{l}\text { Diversity of cultures and religions making } \\
\text { a pluralistic society. }\end{array}$ & $\begin{array}{l}\text { Jackson (2004); } \\
\text { Baum }(2007)^{\mathrm{x}} \text {. }\end{array}$ \\
\hline Relativism & $\begin{array}{l}\text { Arises from the capacity to make multiple } \\
\text { comparisons. Tendency to see religions and } \\
\text { world views as much the same in principle; } \\
\text { hence a decline in sense of religious } \\
\text { uniqueness and in religious authority. }\end{array}$ & $\begin{array}{l}\text { Baum }(1987,2007) \\
\text { Crawford \& Rossiter }(2006)^{\mathrm{XI}}\end{array}$ \\
\hline
\end{tabular}


Graham Rossiter

Understanding the Changing Landscape of Contemporary Spirituality...

\begin{tabular}{|l|l|l|}
\hline Detraditionalisation & $\begin{array}{l}\text { Decline in the sense of family, religious } \\
\text { and cultural traditions; life lived more } \\
\text { independently of cultural traditions. }\end{array}$ & $\begin{array}{l}\text { Hermans (2004); } \\
\text { Boeve }(2003,2005,2011)^{\mathrm{XII}} .\end{array}$ \\
\hline Ideology & $\begin{array}{l}\text { The value basis to a particular way of } \\
\text { thinking, or of a cultural group. The set of } \\
\text { values that motivates and drives particular } \\
\text { political groups. Ideology may be somewhat } \\
\text { covert. }\end{array}$ & $\begin{array}{l}\text { Darder et al (2003); } \\
\text { de Botton (2004) }\end{array}$ \\
\hline $\begin{array}{l}\text { Inter-cultural } \\
\text { communication }\end{array}$ & $\begin{array}{l}\text { The process of promoting mutual } \\
\text { understanding and conversation between } \\
\text { cultural groups. Learning from different } \\
\text { cultures. }\end{array}$ & $\begin{array}{l}\text { Gallagher (1992); } \\
\text { English (1998) }\end{array}$ \\
\hline
\end{tabular}

\begin{tabular}{|l|l|l|}
\hline $\begin{array}{l}\text { Constructs } \\
\text { related to } \\
\text { institutional change }\end{array}$ & \\
\hline De-institutionalisation & $\begin{array}{l}\text { Decline in the prominence and power of } \\
\text { social institutions - like religions. Decrease } \\
\text { in the power of certain bureaucracies. }\end{array}$ & Hermans $(2004)^{\mathrm{xv}}$. \\
\hline
\end{tabular}

\begin{tabular}{|c|c|c|}
\hline $\begin{array}{l}\text { Social psychological } \\
\text { constructs }\end{array}$ & & \\
\hline Meaning and purpose & $\begin{array}{l}\text { The thinking that helps individuals interpret } \\
\text { their experience and the world. It helps } \\
\text { justify and motivate behaviour. It can help } \\
\text { give coherence to one's explanations of what } \\
\text { is happening in the world. Inner resources } \\
\text { that are developed through interaction with } \\
\text { cultural meanings. }\end{array}$ & $\begin{array}{l}\text { Baumeister (1993); } \\
\text { Crawford \& Rossiter (2006) }\end{array}$ \\
\hline Identity & $\begin{array}{l}\text { How individuals draw on both cultural } \\
\text { and inner resources for their self- } \\
\text { understanding and self-expression. May be } \\
\text { multidimensional including moral, spiritual, } \\
\text { religious, cultural, identity elements. }\end{array}$ & $\begin{array}{l}\text { Taylor (1989); } \\
\text { Crawford \& Rossiter (2006) }\end{array}$ \\
\hline Wellbeing & $\begin{array}{l}\text { The general feeling of wholesomeness in } \\
\text { the individual's self understanding and } \\
\text { life. Includes physical, social, spiritual and } \\
\text { economic dimensions. }\end{array}$ & $\begin{array}{l}\text { Eckersley et al }(2005,2006) \\
\text { Fisher }(2000,2001)^{\mathrm{xVIII}} .\end{array}$ \\
\hline Resilience & $\begin{array}{l}\text { Capacity to function well as a person despite } \\
\text { difficulties and problems. Capacity to cope } \\
\text { with setbacks in life. }\end{array}$ & $\begin{array}{l}\text { Brown (2001); } \\
\text { Witham (2001) }\end{array}$ \\
\hline Character & $\begin{array}{l}\text { The moral 'fibre' of the individual. The set } \\
\text { of virtues that gives the individual moral } \\
\text { integrity. The values and commitments that } \\
\text { help make a healthy, contributing citizen. }\end{array}$ & $\begin{array}{l}\text { Bohlin (2005); } \\
\text { Nucci \& Narvaez (2008) }\end{array}$ \\
\hline Virtues & $\begin{array}{l}\text { The moral qualities that are embedded in } \\
\text { the individual like 'habits' of mind and } \\
\text { good behaviour. Has a long history within } \\
\text { thinking about religious virtues. }\end{array}$ & $\begin{array}{l}\text { Swanton (2003); } \\
\text { Koertge }(2005)^{\mathrm{XXI}} \text {. }\end{array}$ \\
\hline
\end{tabular}

I C.Y. Glock, R. Stark, Religion and society in tension. Chicago 1965, Rand McNally; M. Flynn, The Effectiveness of Catholic Schools, Sydney 1985, St Paul Publications; M. Flynn, The culture of Catholic schools: A study of Catholic schools, 1972-1993. Sydney 1993, St. Pauls; 
C. Smith, M.L Denton, Soul searching: The religious and spiritual lives of American teenagers. Oxford 2005, Oxford University Press.

II R.C. Fuller, Spiritual, but not religious: Understanding unchurched America. New York 2001, Oxford University Press; W. Tinsey, The Gospel, church and culture: Historical and contemporary perspectives on mission, evangelisation and the dialogue with culture. Journal of Religious Education, 50 (2002) 3, p. 62-71; J. Sullivan, Leading values and casting shadows in church schools. Journal of Religious Education, 51 (2003) 1, p. 44-49.

${ }^{\mathrm{III}}$ E. Mascall, The secularisation of Christianity: An analysis and critique. London 1965, Darton, Longman and Todd; D. Bonhoeffer, Letters and papers from prison (Translated and edited by Edehard Bethge.). New York 1966, Macmillan; R. Fenn, Beyond idols: The shape of a secular society, Oxford 2001, Oxford University Press; E. Norman, Secularisation. London 2002, Continuum; A. Wright, The justification of compulsory religious education: A response to Professor White, British Journal of Religious Education, 26 (2004) 2, p. 165-74; M. Crawford, G. Rossiter, The secular spirituality of youth: Implications for religious education, British Journal of Religious Education, 18 (1996) 3, p. 133-143; Crawford \& Rossiter, 2006, op. cit.

Iv G. Baum, Man becoming: God in secular experience, New York 1970, Herder and Herder; Crawford \& Rossiter, 2006, op. cit.

$\checkmark$ P.L. Berger, T. Luckmann, The social construction of reality: A treatise in the sociology of knowledge. Garden City NY 1966, Doubleday; P.L. Berger, The sacred canopy: Elements of a sociological theory of religion. Garden City, NY. 1969, Anchor Books; P.L. Berger, The social reality of religion. Harmondsworth 1973, Penguin.

${ }^{\text {VI }}$ R. Jackson, Religious education: An interpretive approach. London 1997, Hodder \& Stoughton; J Olthuis, On Worldviews. Christian Scholars Review, 14 (1985) 2, p. 155-65; D. Naugle, Worldviews: History of a Concept. Grand Rapids MI 2002, Eerdmans.

${ }^{\mathrm{VII}}$ Berger \& Luckmann, 1966, op. cit.; Berger, 1973, op. cit.; H. Blumer, Symbolic Interactionism: Perspective and Method. Englewood Cliffs N.J. 1969, Prentice Hall.

VIII Z. Bauman, Postmodernity and its discontents. Cambridge 1997, Polity Press; F. Bridger, Desperately seeking what? Engaging with the new spiritual quest. Journal of Christian Education, 44 (2001) 1, p. 7-14; Crawford \& Rossiter, 2006, op. cit.

IX P. Halman, R. de Moor, The Individualizing society: Value change in Europe and North America. Tilburg 1993, Tilburg University Press; Crawford \& Rossiter, 2006, op. cit.; F. Schweitzer, The postmodern life cycle: Challenges for church and theology. St Louis MI 2004, Chalice; F. Schweitzer, Religious individualization: New challenges to education for tolerance. British Journal of Religious Education, 29 (2007) 1, p. 89-100; L. Boeve, God interrupts history: Theology in a time of upheaval. New York 2007, Continuum.

${ }^{x} \mathrm{R}$. Jackson, Rethinking religious education and plurality: Issues in diversity and pedagogy. London 2004, Routledge Falmer; G. Baum, Signs of the times: Religious pluralism and economic injustice. Ottawa 2007, Novalis.

${ }^{\mathrm{XI}} \mathrm{G}$. Baum, Pluralism and religious identity. Address at the Conference of the Religious Education Association of Canada and the United States. 1987; Baum, 2007, op. cit.; Crawford \& Rossiter, 2006, op. cit.

${ }^{\mathrm{XII}}$ C.A.M. Hermans, Abductive hermeneutics, in: H. Lombaerts. \& D. Pollefeyt, Hermeneutics and religious education, Biblioteca Ephemeridum Theologicarum Lovaniensium CLXXX. Leuven 2004, Leuven University press \& Uitgeverij Peeters. pp. 95-120; L. Boeve, Interrupting tradition: An essay on Christian faith in a post-modern context, Grand Rapids, MI 2003, Eerdmans; L. Boeve, Religion after detraditionalization: Christian faith in a post-secular Europe. Irish Theological Quarterly, 70 (2005) 2, p. 99-122; L. Boeve, Communicating faith in contemporary Europe: 
Dealing with language problems In and Outside the Church. In J Sullivan (Ed.) Communicating faith. Washington 2011. Catholic University of America Press.

XIII A. Darder, M. Baltodano, R.D. Torres, (Eds), The critical pedagogy reader, New York 2003, Routledge Falmer; A. de Botton, Status anxiety. Melbourne 2004. Hamish Hamilton.

XIV S. Gallagher, Hermeneutics and education. Albany N.Y. 1992. State University of New York; G. English, Participants in an unfinished church: Intercultural communication as a basis for religious education. Unpublished EdD thesis, University of Sydney, Sydney 1998.

${ }^{\mathrm{xV}}$ Hermans, 2004, op. cit.

XVI R.F. Baumeister, Meanings of life. New York 1993. Guilford Press; Crawford \& Rossiter, 2006, op. cit.

XVII C. Taylor, Sources of the self: The making of the modern identity. Cambridge Mass. 1989. Cambridge University Press; Crawford \& Rossiter, 2006, op. cit.

XVIII R. Eckersley, A. Wierenga, J. Wyn, Life in a time of uncertainty: Optimising the health and wellbeing of young Australians. Medical Journal of Australia, 183 (2005) 8, p. 402-404; R. Eckersley, A. Wierenga, J. Wyn, Flashpoints and signposts: Pathways to success and wellbeing for Australia's young people. Canberra 2006. Australia 21 and the Australian Youth Research Centre; J. Fisher, Understanding spiritual health and well-being: Becoming human, becoming whole, Journal of Christian Education, 2000,43(3): 37-52; J. Fisher, The nature of spiritual wellbeing and the curriculum: Some educators' views, Journal of Christian Education, 44 (2001) 1, p. $47-58$.

XIX J.H. Brown, Resilience education. Thousand Oaks, Calif. 2001. Corwin Press; T. Witham, Nurturing spirituality in children and young people by developing resilience, Journal of Christian Education. 44 (2001) 1, p. 39-45.

${ }^{\mathrm{xx}} \mathrm{K}$. Bohlin, Teaching character education through literature: Awakening the moral imagination in secondary classrooms. New York 2005. Routledge Falmer; L. Nucci, D. Narvaez, Handbook of moral and character education. New York 2008. Routledge.

xxI C. Swanton, Virtue ethics: A pluralistic view. New York 2003. Oxford University Press; N. Koertge, Scientific values and civic virtues. Oxford 2005, Oxford University Press.

Cultural meanings: The construct or conceptual scheme that will be used here is change incultural meanings ${ }^{4}$ Cultural meanings are understood as the sets of socially constructed ideas, values, assumptions and emotions that inform people's thinking and behaviour. Cultural meanings are distinctive of particular social and ethnic groups and religions; but they also operate across the social context from family to nation state, and increasingly at a global level. While there are many cultural meanings in a society, it is possible to identify the sets of meanings with which individuals or groups identify. They are like the background ideas about life (thinking and assumptions) that people draw on to explain or justify their behaviour. They condition the way people think about their lives. Trying to identify the active cultural meanings for individuals tries to interpret their 'self interpretations'.

\footnotetext{
4 Crawford \& Rossiter, 2006, op. cit., p. 46-59.
} 


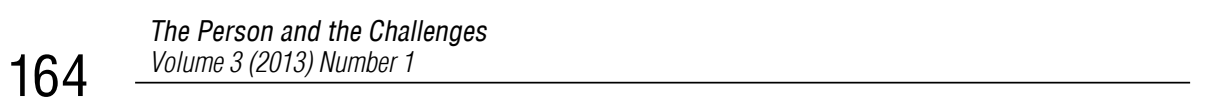

Cultural meanings are often a blend of social, cultural, religious, spiritual and political ideas that are in turn meshed with feelings and values that reinforce the ideas. People draw on and interact with these cultural meanings when forming their own personal ideas about life. It is like the 'atmosphere of meaning' that people are continuously 'breathing in'; and it is like the immediate 'thinking/feeling environment' they inhabit which affects how they interpret reality and what they do. These meanings are associated with various sources - family, social and cultural groups, religion, nation state and the wider popular culture. Individuals may draw on particular sources or reference groups while shunning others, and they may also draw from a wide range of meanings in an eclectic fashion. There will be a diversity of responses to the same perceived cultural meanings; for example, what is 'liberal' to some will be regarded as 'harmful' and 'deviant' by others ${ }^{5}$. Whatever the idiosyncratic personal meaning they construct, it cannot be fully understood apart from the particular landscape of meaning within which it developed. Some will be both conscious and articulate about the cultural meanings they have adopted; others may be relatively unaware of their social conditioning - as if it was just 'natural reality' which is not usually questioned.

Religion can be prominent and influential in people's accepted cultural meanings. Others can identify with religion nominally while their behaviour suggests that they are really operating more out of the common cultural meanings in their society. Still others would see their key meanings, and hence their spirituality, as unrelated to religion.

The notion of cultural meanings is a composite scheme that draws on a number of the constructs listed in table 1 - especially Berger and Luckmann's (1966) understanding of social reality where people's knowledge and behaviour are interpreted as closely related to what they construe to be reality, together with the recognition that social reality is constructed by individuals and groups; also there is some similarity with symbolic interactionist theory ${ }^{6}$ (Blumer,

5 For example: While the Catholic Bishops document (Catholic Bishops of NSW \& ACT. Catholic schools at a crossroads: Pastoral letter of the Bishops of NSW and the ACT. Sydney 2007. Catholic Education Office) regards the low mass attendance of Catholic youth as a problematic decline in spirituality, researchers such as Hughes (P. Hughes, Putting life together: Findings from Australian youth spirituality research. Fairfield, VIC 2007. Fairfield Press.) are more positive, accepting this as an expression of a more personal and less institutionally oriented spirituality.

6 Symbolic interactionism considers that individuals develop interpretations of their environment and then act on the basis of those interpretations. They interpret meanings through 
1969). Investigating cultural meanings tries to identify and evaluate what appear to be the important, driving ideas and assumptions behind people's thinking and behaviour. It is essentially interpretive and hypothetical in process; it acknowledges that individuals may or may not advert to the cultural meanings that affect their behaviour, because these meanings can be taken for granted parts of their social world that do not need articulation, let alone evaluation. If cultural meanings are not brought into the open for appraisal, they can remain deviously influential because they are then regarded as a natural, but hidden part of the normal fabric of life. The sociologist Raymond Williams proposed that by starting with the identification and appraisal of cultural meanings, individuals can take up cultural agency, where they can avoid being just passive 'consumers' of culture by actively contributing to the creation of cultural meanings within their own sphere of influence. This approach is consistent with much of the thinking in critical theory and critical pedagogy ${ }^{8}$.

Cultural meanings serve as communal frames of reference that are available to people in the working out of their own personal frame of reference or personal meaning. They usually act in ways that are more or less consistent with their personal meanings. Both personal frame of reference (difficult to characterise) and cultural meanings (more easily identified) are keys to

the lens of socially created symbols and ideas, thus construing their personal sense of reality within the cultures that impact on and inform their lives.

7 Williams' ideas about the need to critically evaluate cultural meanings is discussed in M. Warren, Communications and cultural analysis: A religious view. Westport, Conn 1992, Bergin $\&$ Garvey.

8 Darder et al. 2003, op. cit. Critical theory is a collective term covering a number of theoretical developments in philosophy, sociology, the humanities and social sciences that occurred mainly in the last half of the $20^{\text {th }}$ century. Influenced by Marxism and structuralism, as well as by more recent trends in post-structuralism and postmodernism, it has a political focus and a concern for social change. The word 'critical' is consistent with the special attention it gives to the interpretation and critique of society, particularly the critique of domination - in the pursuit of social justice and the emancipation of marginalised groups. It tries to penetrate beneath objective appearances to expose the underlying social relationships they often conceal - in other words, exposing, through critical analysis, social relationships that took on the status of things or objects. For example, a projection of the 'good life' could be little more than subtly promoting a 'satisfying consumerism', thus reducing it to the exercise of purchasing power.

critical pedagogy is concerned with the pedagogical implications of critical theory - mainly for the education of adults, but with an interest in school education. It calls into question the role of schools in 'reproducing' society - that is, in reinforcing the assumptions and values of the dominant groups (especially in commerce) and of the 'industry' of cultural reproduction. It considers how values and attitudes could constitute a 'hidden curriculum' in schools, precisely because they are not identified and acknowledged. 
interpreting behaviour. Hence, identifying cultural meanings and showing how they have changed is a useful way of interpreting change in spirituality.

It is difficult to estimate with accuracy the way in which cultural meanings affect individuals. It seems to be a natural part of the human condition to have difficulty in determining the extent to which various cultural meanings affect us. It is often appears easier to see how they may have affected others - even though such interpretations may be incomplete. But by identifying the range of factors that influence people's cultural and personal frames of reference, we are in a better position to understand personal and social change as it is manifested in spirituality. And in turn, this interpretation can be useful educationally for helping people look more critically at the cultural meanings that have had a shaping influence on them. These factors can be life enhancing as well as life inhibiting. They can extend freedom just as they can limit it. The educational hope is that individuals become better educated with respect to the social forces that may have a conditioning influence on the way they live their lives. By interrogating the cultural meanings that affect society and individuals, people are in a better position to make informed choices and to address contemporary spiritual and moral issues ${ }^{9}$. This provides a potentially valuable contribution to religious education (and education generally) both in content and pedagogy; students could be engaged in a research-oriented process of appraising cultural meanings; at a personal level, they would have the opportunity to reflect on where their personal frame of reference related, if at all, to the cultural meanings being evaluated.

Change in cultural meanings: There are two main aspects to change in cultural meanings:

Firstly, there is the emergence and dissemination of new cultural meanings;

Secondly, individuals change the cultural meanings to which they are subscribing; they switch their allegiance to new meaning $\mathrm{s}^{10}$ available in the culture; this change may be gradual and sometimes almost imperceptible.

9 B.V. Hill, Is value(s) added education in the national interest?, Harold Wyndham Memorial Lecture, Sydney 1993, NSW Institute of Educational Research.

${ }^{10}$ For example, some Catholics have shifted their thinking away from the traditional view that good Catholics go to Mass every Sunday and are involved in parish life to a more individualised interpretation of what it means to be a contemporary Catholic - where they feel they have internalised the core of Catholic beliefs and values while not needing to be so formally linked with the Church's institutional life. Their switch in allegiance both justifies and supports their change in 
Individuals and groups are forever inventing and disseminating cultural meanings - new ways of interpreting life. The religious cultural meanings associated with any group will evolve and change over time in response to new circumstances. Sometimes the 'new' meanings are really 'recycled' 'old' meanings. It could be expected that very traditional, mono-cultural societies would have less variety in cultural meanings than pluralistic, multi-cultural societies. Being able to make multiple comparisons between diverse religions, world views and lifestyles could also be expected to be a catalyst for people to change their cultural meanings; dissatisfaction with old meanings and the allure of the new could prompt change. However, if individuals were secure in their reference group, and if they felt it had a strong identity and self-sufficient plausibility, then they could be unmoved by the variety of meaning systems on offer; they could feel relatively impervious to inroads from competing meanings, particularly those that might call their own system into question. Some who are anxious about the multiplicity of competitive meaning systems, retreat defensively into the security of their own reference group ${ }^{11}$ For minority groups, particularly when oppressed, their meaning system is important in group identity and perhaps even for cultural survival; it provides inner strength.

A variety of life experiences could trigger change in the personal meanings of individuals - including education. The new personal meanings usually resulted from a shift in their favoured cultural meanings. It is not that they created new meanings as such, but they moved towards meanings that made more sense of their experience and with which they felt more comfortable. It may have been a response to perceived dissonance - where their experience was increasingly being felt to be inconsistent with the explanations offered by their old meaning system ${ }^{12}$.

formal religious practice. They will also see this switch in terms of a change in reference groups to a different group of Catholics.

${ }^{11}$ This helps explain why some will feel more secure and at home within a relatively conservative (andsometimes more authoritarian) group within their own denomination. Further, it is also a factor that leads some into fundamentalist groups; and it can also incline some to join sects and cults. Crawford \& Rossiter (2006, op. cit. p. 69) explained how individuals depend on institutions and authorities for meaning to various extents; and how in some instances they 'bolster' their personal meanings with fundamentalism because it appears to them to have strong, self-evident truth claims.

${ }^{12}$ L. Festinger, A theory of cognitive dissonance. Stanford 1962, Stanford University Press. 
If the old reference group appeared to be losing its plausibility - where its value was no longer self-evident - individuals tended to look elsewhere for more meaningful ideas to motivate and explain their lives. This prompts a migration in reference groups. During this process, individuals may pay more attention to the critiques of their old reference group which were available in the wider community. The credibility of the old system declines; its meanings appear to lose their relevance and explanatory power, and consequently their capacity to retain people's allegiance fails. Sometimes the change is led by action; individuals behave in new ways; they may change the emphases in their lifestyle; then because they feel comfortable with this new behaviour, they eventually make adjustments to their personal meaning system - they change their 'subscription' to new cultural meanings that better accommodate their behaviour and interests. It may have been a relatively imperceptible drift into new ways of thinking.

Change in cultural meanings is inevitably connected with how they are constructed and communicated. Human history shows that story-telling and its preservation in writing have been important in the handing on of cultural meanings from generation to generation; stories are meaning-embedded narratives. New media for communication have helped maintain and conserve cultural meanings, as well promote the spread of new meanings. Print, telephony, radio, film and television have contributed, and now there are emails, texting and the internet - together with its social networking sites such as Facebook, G Plus, YouTube, MySpace and Twitter, and individual blogging. More will be said about the influence of electronic communication later.

Change in spirituality is not only affected by theological development within religion but also by changes in the background cultural meanings about life. In a text on modern European thought, Boumer ${ }^{13}$ wrote about the process of secularisation in a chapter entitled 'The Eclipse of God'. He began with the words of Dietrich Bonhoeffer, writing from prison in 1944. "The secular movement which I think had begun in the $13^{\text {th }}$ century has in our time reached a certain completion. People have learnt to cope with all the questions of importance without recourse to God as a working hypothesis. In questions concerning science, art and even ethics this has become an understood thing which one scarcely dares to tilt at anymore"14.

${ }^{13}$ F. L. Boumer, Modern European thought: Continuity and change in ideas, 1600-1950. New York 1977. Macmillan. P. 439.

${ }^{14}$ Bonhoeffer, 1966, op. cit. p.194. 
Amongst other things this suggests two key points for understanding change in spirituality. Firstly, the centrality of ideas about God; and secondly, that the origins of change need to be traced back to medieval times.

\section{Cultural meanings in a traditional religious spirituality}

Consider the situation of people in $12^{\text {th }}$ century Christian Europe. For an illiterate peasant leaving his small wooden or mud house, with no windows, and entering a massive cathedral - for example, in Ely, Salisbury or Chartres - the contrast would have been awe inspiring; the physical 'house of God' reflected a sense of the divine on earth. The size and height of the vaulting, the stained glass windows and the frescoes and paintings would have helped communicate a sense of the transcendence and power of god who presided over the world. Apart from the castles and houses of the nobles, the cathedrals would have dominated the city skyline, symbolic of the dominance of god and religion. In the small villages, this was replicated in miniature with the local church spire often the most prominent landmark. The dominance of Christian cultural meanings in $12^{\text {th }}$ century France was evident in one estimate that there was one ecclesiastical structure of some kind for about every 200 people. A comparable situation exists today in some places - for example, across the hundreds of square kilometres of villages along the Nile near Luxor in Egypt; the spires of the local mosques are particularly prominent at night because they are lit with blue fluorescent lights; they dot the landscape about every kilometre or two from horizon to horizon. This religious domination of the landscape was symbolic of the overwhelming dominance of cultural religious meanings that regulated the lives of people in such contexts.

The authority of God, the spiritual/moral power of the church (religion) and the political power were usually amalgamated into a single network of cultural religious meanings. It covered all aspects of life and was relatively inescapable. It gave people a sense of their own 'station in life' within a system that was usually accepted without question; it gave them meaning and purpose and a sense of personal dignity; and it regulated their activity in minute detail. Within this system, it would be difficult to find meanings and practices that did not have a religious overlay. And all of this helped ensure (and enforce?) social stability. It would have been difficult to contemplate 
cultural meanings outside the prevailing system - there appeared to be few if any alternatives; if there were other religious groups present, they would have been in a minority and not likely to challenge the status quo. Born into this system, individuals simply absorbed its meanings as reality - there was no sense that it was socially constructed; any questioning of the system was likely to be judged as a deficiency in faith.

Six key meanings permeated the common spirituality in this context:-

1. The centrality of God who was perceived as the creator and end of the human race as well as its judge.

2. Life and religion were focused on heaven as the 'true' life for which life on earth was a preparation; this tended to make religious meanings the compelling spiritual and moral reference points for thinking and behaviour.

3. The power of the church (religion) over individuals, usually in concert with political power, was absolute; authorities were supreme; deviants or heretics could be put to death; many religious cultural rituals set the pattern for daily life in an annual cycle.

4. Obedience was a prominent aspect of most human interactions. Obedience to God was aligned with obedience to the church (religion). Authorities, both religious and political, were respected without much question.

5. Fear was a strong motivating factor; fear of God merged into fear of religious and political authorities; the idea of reward for the good and punishment of evil was a prominent moral motivation; the ultimate fear was of eternal punishment in hell.

6. Evil in the world was personalised in the form of the Devil; the Devil - the 'tempter' - was held responsible for much of went wrong in personal and social life.

There was a strong feeling of tight control over people's lives and spirituality. The meanings underpinning their spirituality were a mix of belief, theology, opinion, fears and superstition. One could speculate that the extent to which this profile varied for individuals was limited, even though it may have been likely to be different for the ruling class, clergy and the educated.

The unquestioning acceptance of religious meanings as reality reinforced a literal interpretation of sacred writings. For example, the Genesis and Gospel stories were historicised. 


\section{Changes away from a traditional religious spirituality understood in terms of change in cultural meanings}

This section will consider only some of the changes in cultural meanings that have contributed to a move away from traditional spirituality. The pattern of change since the middle ages needs to be identified even in broad outline because it not only describes historical, cultural change in spirituality, but also because a similar pattern is often evident at a psychological level in individuals when their traditional spirituality morphs into something that is more secular and individualistic.

A change from traditional religious spirituality was particularly evident in three areas of cultural meanings:

1. Understanding of god and of the creator's role of the universe.

2. The power that religious authorities had over the lives and thinking of individuals; less fear of religious authorities.

3. Decline in the prominence of religious ritual and religious references in social life.

The following, among many factors, contributed to the secularisation of spirituality in Europe (and later in the Americas) since the middle ages.

Movement of people into the developing cities. There was (and still is the case to some extent) more stability, sameness and less variety to life in villages. Large scale movement to the cities exposed people to a greater variety of occupations, interests and lifestyle components. While there may still have been limited opportunities in the city, it expanded their thinking about life - even though the industrial revolution often resulted in a new form of domination of people's lives by work. They could make comparisons between their lives and what others thought and did. The cities were the breeding grounds for the notion of a popular, common culture that gradually differentiated from the official religious/political monoculture; these were the first signs that there was scope for thinking differently about life.

Separation of church (religion) and state. In the various formats with relative separation of church and state and various levels of democracy, there was some breakdown in the total dominance that the previous religious/political monoculture had exercised over people's thinking. Eventually, people could not be legally executed for supposed heresy and witchcraft. Fear of religion, and an accompanying fear of god, declined. This supported the development 
of a more widespread sense of freedom, autonomy and individuality, even if people did not have unlimited scope to change their station in life.

Change away from the predominantly religious subject matter of art. Previously most art was on traditional religious topics. While the subject matter of art was not so much a change factor in itself, it was an indicator of changing cultural meanings; and since the Renaissance there was much more humanistic and less religious art. This was one of the first significant signposts of secularisation.

The rise of science, scientific thought and the enlightenment. While the rise of scientific thought and enlightenment rationalism may have affected the educated more than the uneducated, in the emerging common or popular cultural meanings, it further eroded the plausibility and power of the previously unquestioned religious authority. There were new ways of thinking about the cosmos and about human origins and purposes; and reason could provide a rationale for living along side a religious interpretation. Some integrated these ideas within their developing spirituality and theology while others did not. For example, evolutionary theory resulted in a polarisation of meanings between those who accepted it and those who retained a creationist account - while for some it was a reason for abandoning religious beliefs altogether ${ }^{15}$.

\section{Interpretation of human behaviour through the human sciences:} Psychology and sociology provided new relatively scientific ways of interpreting and explaining human behaviour. In turn, these meanings led to different, not necessarily religious, ways of understanding personal development. On the fringes of the human sciences, various self-help programmes and parapsychological movements also developed.

Education: The development of compulsory schooling and the increasing number of years spent at school gradually raised both the general level of community education and critical literacy. This would have contributed to increased individualism in thinking ${ }^{16}$.

${ }^{15}$ Crawford \& Rossiter (2006, op. cit. p. 72-76) provided an interpretation of this problem, showing how clashes arose between scientific and religious meanings and how this is evident in contemporary understandings of human origins. They also identified problems related to children's learning to make distinctions between scientific and religious meanings. If they do not learn to do this, there is a danger that they can dismiss religion on the basis of a naïve scientism.

${ }^{16}$ Since the origins of compulsory schooling, school education has not only increased the general level of public knowledge in numeracy and literacy, it has affected people's critical 
Technologies for the communication of cultural meanings. As noted in an earlier section, technologies that 'extended' the written and spoken word provided increased opportunities for exposure to different cultural meanings. Traditional reference points like home, ethnicity, religion, school and nation might be expected to be basic sources for images of life and values; other no less significant sources can be peers, social and recreational groups. But in modern times these influences are superseded by the 'storying' role of film and television with their meaning-embedded narratives about life that can eclipse the stories that have traditionally informed spiritual development and identity. Gerbner ${ }^{17}$ drew attention to the significant change in traditional patterns of storytelling that was enabled by film and television: "We have moved away from the historic experience of humankind. Children used to grow up in a home where parents told most of the stories. Today television tells most of the stories to most of the people most of the time". Similarly, Australian scholars Eckersley et. al. considered that "when a community abdicates the role of storytelling to the mass media, particularly commercial media, a focus on wellbeing or the good life is diminished to stories about feeling good. These stories can have a very individual focus"18. This suggests that the media and advertising industries create a social reality that for many people has become their major moral and spiritual reference point.

All these examples of change factors worked in favour of the emergence of two new cultural meanings that would drive the development of secular individualistic spiritualities.

Firstly, there was the sense of an alternative set of popular cultural meanings about life that was more or less independent of the traditional religious view; individuals could now compare what was expected formerly with what was encouraged, allowed or tolerated within the popular culture. There were options for thinking about life that were not there before. Whereas there had been one pervasive, mono-cultural, religious system that dominated

thinking. It has helped them to become more discerning, and more independent and self confident because they are better informed about social issues and more confident in their own judgment. Hence, school education has been important in advancing the agenda of individualism.

${ }^{17}$ G. Gerbner, The Challenge of Television, Unpublished paper quoted in Warren, M. Communications and Cultural Analysis: A religious view, Westport, Connecticut 1992. Bergin and Garvey.

${ }^{18}$ Eckersley et al. 2006, op. cit., p. 35. 
$174 \quad \begin{aligned} & \text { The Person and the Challenges } \\ & \text { Volume } 3 \text { (2013) Number } 1\end{aligned}$

cultural meanings, people were now becoming accustomed to multiple frames of reference for life's meaning.

Secondly, more attention and power were being given to the individual's own autonomous, personal frame of reference for providing the ultimate criteria for judging spiritual/moral matters. The traditional cultural reference point in religion and religious authorities declined in plausibility and power; it was becoming perceived as having more of an 'advisory' role than a 'normative' one. While many would be inclined towards this more individualistic approach, others remained attached to the external authority as their prime frame of reference.

\section{Cultural meanings associated with a relatively secular, eclectic, individualistic spirituality}

This section concludes the article with a tabular summary contrasting the different cultural meanings that informed both traditional and contemporary spiritualities. It has been included because it is the one piece of writing that has been used most successfully with postgraduate education students ${ }^{19}$ in persuading them that the change in spirituality has been so substantial that not to take it into account would constitute a failure in the mission of Catholic school religious education.

The comparisons in Table 2 show how significant polarities have developed in the way people develop meanings that inform their lives. In particular, they show how religion is referred to in different ways - from being the traditional, authoritative source of meaning to one of a number of possible resources that one can draw from as 'advisory' rather than normative. While not all individuals will fit comfortably within these descriptions, the contrasting indicators provide a useful picture of the polarities that developed in the cultural change process. This summary has drawn particularly on the ideas of Eckersley ${ }^{20}$ and to a lesser extent on Crawford \& Rossiter (2006) and Schweitzer (2004, 2007).

19 This table was developed by the author for use in Master of Religious Education units at Australian Catholic University, and has been identified generally by the participating students as the most compelling piece of writing that helps them put changes in spirituality into perspective. Hence its place in this article was judged as pertinent if the article's purpose is about raising critical consciousness of the need to address contemporary spiritualities positively in religious education.

${ }^{20}$ R. Eckersley, Well and good: Morality, meaning and happiness, Melbourne 2005, Text Publishing. 
Table 2. Contrasts between the cultural meanings underpinning traditional and contemporary secular spiritualities

\begin{tabular}{|c|c|}
\hline $\begin{array}{l}\text { Trends in cultural meanings in } \\
\text { a relatively traditional society, and } \\
\text { to some extent in individuals with } \\
\text { a traditional religious spirituality }\end{array}$ & $\begin{array}{l}\text { Trends in cultural meanings in contemporary } \\
\text { Westernised societies, and in individuals with } \\
\text { a secular, individualistic spirituality }\end{array}$ \\
\hline $\begin{array}{l}\text { Personal meaning was usually a social } \\
\text { given. A religious meaning system was } \\
\text { received like a set package; it was 'taken- } \\
\text { for granted' and internalised. } \\
\text { There was security in having a relatively } \\
\text { 'black and white' meaning system and } \\
\text { moral code. } \\
\text { Individuals did not have to 'search' for } \\
\text { meaning; they had a ready made package. } \\
\text { The religious meaning system may have } \\
\text { been experienced as somewhat harsh and } \\
\text { oppressive, but it helped people make sense } \\
\text { of their lives at several levels, answering } \\
\text { the fundamental questions: Who am I? } \\
\text { Where have I come from? Why am I here? }\end{array}$ & $\begin{array}{l}\text { Meaning in life was now less a social given and more } \\
\text { a matter of personal choice; personal meaning was } \\
\text { 'constructed' by individuals for themselves, or chosen } \\
\text { from a proliferation of options. } \\
\text { There was a challenge to individuals in constructing their } \\
\text { own DIY (Do It Yourself) spirituality. } \\
\text { 'Searching' for meaning and taking responsibility for } \\
\text { developing one's own personal meaning system could be } \\
\text { stressful. } \\
\text { The speed, scope and scale of economic, social and } \\
\text { cultural change have made the past seemingly irrelevant } \\
\text { and the future uncertain for many. This seems to have } \\
\text { created more 'cultural agnosticism' about meaning, } \\
\text { purpose and certainty in life. } \\
\text { Even if life's meaning was less clear, life itself became } \\
\text { more comfortable, more varied, safer, healthier and } \\
\text { longer. }\end{array}$ \\
\hline $\begin{array}{l}\text { Religious belief: Beyond the mortal } \\
\text { realm, people had a religious faith that not } \\
\text { only provided them with a road map for } \\
\text { life, but it gave them a sense of place in } \\
\text { the cosmic scheme of things. }\end{array}$ & $\begin{array}{l}\text { While many retained some form of religious belief, this } \\
\text { was not nearly as absolute and binding as it once was. } \\
\text { The individual's own experience tended to became } \\
\text { the touchstone for authenticity, and even for what was } \\
\text { regarded as the 'truth'. While nominally linked with } \\
\text { religion, some see a clear distinction between their own } \\
\text { personal faith and the faith taught by traditional religious } \\
\text { institutions. }\end{array}$ \\
\hline $\begin{array}{l}\text { Religious authority: Religious spirituality } \\
\text { (in the West) was sustained and validated } \\
\text { by church authority. Its plausibility } \\
\text { depended on high regard for the church; the } \\
\text { notion of the authority of god underpinned } \\
\text { church authority. } \\
\text { An emphasis on obedience to religious } \\
\text { authorities and to God. }\end{array}$ & $\begin{array}{l}\text { Authority of the individual: The plausibility of religious } \\
\text { authorities tended to be low. Increasingly, individuals } \\
\text { became their own spiritual authority, deciding for } \\
\text { themselves on the basis of their own judgment about } \\
\text { particular aspects of spirituality."People assumed that } \\
\text { their lives are not predetermined by birth and social } \\
\text { origin, and that every one has the right and also the } \\
\text { responsibility to shape his or her life according to their } \\
\text { own wishes and life plans.".l. It is taken for granted that } \\
\text { everyone has the right to choose their own faith and that } \\
\text { no-one should interfere with their choices. } \\
\text { Little if any regard for religious authorities. } \\
\text { What suited the individual became the ultimate criteria } \\
\text { for the utility of spirituality. }\end{array}$ \\
\hline $\begin{array}{l}\text { The existence and image of God: There } \\
\text { was a strong belief in the existence of God. } \\
\text { The image of God included the notions } \\
\text { of:-creator, all-powerful, benevolent, } \\
\text { loving and caring for each individual, } \\
\text { judge of good and bad, rewarder of the } \\
\text { good and punisher of the evil, listens to } \\
\text { people's prayers and requests for help. }\end{array}$ & $\begin{array}{l}\text { A natural uncertainty about the existence of god became } \\
\text { more prevalent. Belief in a benevolent god was attractive } \\
\text { and comforting, but not something that many individuals } \\
\text { counted on or thought much about. }\end{array}$ \\
\hline
\end{tabular}


Family and community ties: Children usually grew up in a close network of family and community relationships that largely defined their world - their values, beliefs, identity and station in life.

The world outside: Most people knew relatively little of what lay outside their world, and of other ways of living (in pretelevision times).

Social change and the predictability of life: Much of life was predictable and what was not was explained in terms of the supernatural and religious belief.
Family and community ties were loosened. Consequently individuals appeared more open to various life options available in the wider culture, together with more individualism in their choices.

People know much more of the rest of the world and how differently others lived and thought. Information about what was happening around the world was available instantaneously.

Rapid social change resulted in much more uncertainty about life and the future. Many accommodated to the uncertainty as 'natural'.(Others could not cope with the uncertainty so well, and identified with communities where meanings were more definite and authoritarian - a move back towards a more traditional setting).

Schweitzer, 2007, op. cit. p. 90.

\section{Conclusion: A starting point for considering implications for Catholic school religious education - the need for a 'foot in both camps'?}

Many religion teachers in Catholic schools in Australia have more personal affinity with thinking in the right column than the left in table 2 . But in religious education, they feel their normative curriculum context sits mainly within the meanings in the left column, while most of their students are at home in the meanings in the other column (even if the description of a traditional spirituality today does not fit neatly within the left column). And if their prescribed purpose in religious education is understood primarily as persuading young people that they need to engage with the church, this can be perceived by their students as wanting to shift their thinking and spirituality towards that of the left column; and the students, and most of their teachers, know that there is no ready educational (or any other) formula that will make this happen. The change in spirituality summarised in table 2, at least in Westernised countries, is considered not to be reversible.

Hence, it is proposed that the starting point for a more relevant religious education is to accept that a relatively secular spirituality is going to be the descriptor for most young people. If this was taken into account more seriously in Catholic religious education documents, it could help change the focus from trying to eliminate and replace contemporary spirituality towards trying to diagnose and address its needs constructively - responding to the opportunity to enhance young people's spirituality whether it is religious 
or not. ${ }^{21}$ And while access to the traditional religious heritage remains a valuable part of education in spirituality for secular youth, more specific attention needs to be given to content and pedagogy that take into account the healthy possibilities as well as the problems within the cultural meanings described in the right hand column.

This article has provided an interpretation of change in the landscape of spirituality that hopefully will help school religious educators understand better the spiritual starting points of young people in contemporary culture - in a way that is less confusing than making use of multiple explanatory sociological constructs. It tries to respond to the calls of the recent popes to scrutinise the influence of culture on spirituality and faith. It is in keeping with the view of Pope Paul VI that: “...the kingdom which the Gospel proclaims is lived by men who are profoundly linked to a culture, and the building up of the kingdom cannot avoid borrowing the elements of human culture or cultures. Though independent of cultures, the Gospel and evangelization are not necessarily incompatible with them; rather they are capable of permeating them all without becoming subject to any one of them. The split between the Gospel and culture is without a doubt the drama of our time ...[culture needs] to be regenerated by an encounter with the Gospel" 22 .

It also sets out to inform an optimistic approach to addressing the needs of contemporary young people's spirituality - an optimism inspired by the final words attributed to Pope John XXIII before his death: "Today's world, the needs made plain in the last fifty years, and a deeper understanding of doctrine have brought us to a new situation ... It is not that the Gospel has changed, it is that we have begun to understand it better. Those who have lived as long as I have ...were enabled to compare different cultures and traditions, and know that the moment has come to discern the signs of the times, to seize the opportunity and to look far ahead" 23 .

${ }^{21}$ This purpose has currency in non-denominational and state based religion studies courses where the concern to hand on a particular religious tradition and nurture personal faith within the context of a local community of faith is not present.

${ }^{22}$ Pope Paul VI, Evangelii nuntiandi, 1975, \#20. Vatican Website http://www.vatican.va/ holy_father/paul_vi/apost_exhortations/documents/hf_p-vi_exh_19751208_evangelii-nuntiandi_ en.html (7.2.2013).

${ }^{23}$ Pope John XXIII, Statement 24 May 1963.http://vatican2voice.org/2need/deroo.htm (07.02.2013). 


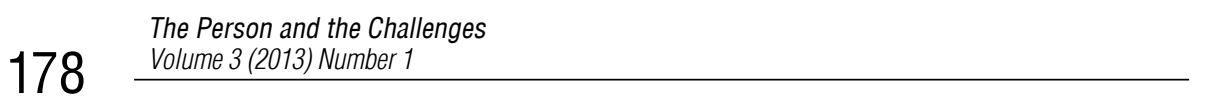

This article is like the first part of a two episode study of the topic. It has provided an interpretation of the rise of contemporary spiritualities that are increasingly the norm for the majority of students in Catholic schools in Australia (and possibly in different school types in other parts of the world.)The planned follow up article will address specifically how religious education in Catholic schools needs to change, to respond to the move away from traditional religious spirituality; it will follow up in detail the brief suggestions in the introduction to this article; it will describe how Catholic school religious education needs to combine the study of religious traditions with an exploration of issues that affect what can be called the 'basic, human, psychological spirituality' of young people; it will consider how spirituality might be approached in the classroom, acknowledging the increasing differentiation between the spiritual and the religious.

\section{Bibliography}

Boeve L., Religion after detraditionalization: Christian faith in a post-secular Europe, „Irish Theological Quarterly”,70 (2005) 2, p. 99-122.

Boeve L., Communicating faith in contemporary Europe: Dealing with language problems In and Outside the Church, In J. Sullivan (Ed.) Communicating faith. Washington 2011. Catholic University of America Press.

Crawford M., Rossiter G., Missionaries to a teenage culture: Religious education in a time of rapid change. Sydney 1988. Christian Brothers Province Resource Group.

Crawford M., Rossiter G., Reasons for living: Education and young people's search for meaning, identity and spirituality. Melbourne 2006. Australian Council for Educational Research.

Eckersley R., Well and good: Morality, meaning and happiness. Melbourne 2005. Text Publishing.

Eckersley R., Wierenga A., Wyn J., Flashpoints and signposts: Pathways to success and wellbeing for Australia's young people. Canberra 2006. Australia 21 and the Australian Youth Research Centre.

Francis L.J., Robbins M., Urban hope and spiritual health : The adolescent voice. Peterborough, UK 2005. Epworth.

Hughes P., Putting life together: Findings from Australian youth spirituality research. Fairfield, VIC 2007. Fairfield Press.

Mason M., Singleton A., Webber R., The spirit of Generation Y: Young people's spirituality in a changing Australia. Melbourne 2007. John Garratt.

Pope John Paul II, Homily, University of Laval Stadium Quebec City, Canadian Catholic Review, 1984, October, 323-325. 
Schweitzer F., The postmodern life cycle: Challenges for church and theology. St Louis MI 2004. Chalice.

Schweitzer F., Religious individualization: New challenges to education for tolerance. British Journal of Religious Education. 2007 29(1) 89-100.

Smith C., Denton M.L., Soul searching: The religious and spiritual lives of American teenagers. Oxford 2005. Oxford University Press.

Sullivan J. (Ed.), Communicating faith. Washington 2011. Catholic University of America Press.

Warren M., Communications and cultural analysis: A religious view. Westport, Conn 1992, Bergin \& Garvey. 